\title{
The Effects of Interest Rates and Taxes on New Car Prices
}

\author{
Maura P. Doyle* \\ Federal Reserve Board of Governors \\ Stop 82 \\ Washington, D.C. 20551
}

July 1997

\begin{abstract}
Utilizing the Consumer Expenditure Survey and state-level variation in taxes, this study finds that prices for most models of new cars shift by more than the amount of a sales tax. The evidence of an overshifting of prices offers support for the recent models of tax incidence in imperfectly competitive markets. The results also suggest that changes in the after-tax interest rate have offsetting effects on new car prices; a one percentage point increase in the after-tax real interest rate will prompt, on average, a mark-down of $\$ 106$.
\end{abstract}

${ }^{*}$ The views in this paper do not necessarily reflect those of the Board of Governors of the Federal Reserve System or its staff. I am grateful to Doug Elmendorf, Steve Sheffrin, and Chris Snyder for helpful comments, to Upacala Mapatuna and Alak Goswami for excellent research assistance, to Bill Passero for assistance with the Consumer Expenditure Survey, to Joe Beaulieu for providing me with data on suggested retail prices and to Dan Feenberg for assistance with TAXSIM. I retain all responsibility for errors. 


\section{Introduction}

Oftentimes, the government attempts to influence consumption patterns with its policy tools, including taxes and interest rates. Consumer spending on durable goods can affect the overall health of the economy and, thus, it is useful to understand the link between these policy tools and durable good consumption. Ultimately, however, both the quantity consumed of a good and the price of a good may respond to government intervention; the results depend, at least in part, on the market characteristics of the good in question. To completely grasp the impact of a government action on both consumers and producers requires an understanding of its impact on both prices and quantities. For example, an interest rate increase may not affect real motor vehicle sales if the automakers are able to counteract the rate increases with lower prices. Nonetheless, it would still not be true that the interest rate had no effect on the motor vehicle industry. To illuminate these effects, this study examines the relationships between taxes, interest rates and the price of a new car.

Empirical evidence relating policy to price remains sparse. The lack of empirical measures may force policymakers to evaluate a policy by relying on untested assumptions. For example, a Congressional Budget Office [1992] study on the effect of adopting a value-added tax relies on standard perfect-competition assumptions that imply prices will increase by the same amount as a newly imposed sales tax. This study will focus on motor vehicle prices. I examine the motor-vehicle industry for several reasons: first, motor vehicles are an important durable good; second, the performance of the industry has a significant impact on the overall economy; third, the industry is likely to be characterized by imperfect competition; finally, there is unusually rich data available for the industry.

This paper establishes empirically the link between the cost of a new car and two distinct policy instruments, the sales tax and the after-tax real interest rate. Because both 
interest rates and the tax deductions on interest payments influence the effective after-tax real interest rate for consumers, the results may provide information that is pertinent for both monetary and fiscal policy.

Few studies address the relationship between taxes, interest rates and consumer durables. Mankiw [1982] and Bernanke [1985] consider models of durable good consumption with the assumption of a constant real after-tax interest rate. Mankiw [1985] relaxes this assumption somewhat, and measures the interest rate sensitivity of durable good expenditures using aggregate data, but assumes a constant marginal income tax rate of 0.3 percent. He finds that consumption of consumer durables is more sensitive to after-tax interest rates than of non-durables or services.

Using micro-level data and the cross-sectional variation in the tax code, I am able to determine whether the benefits of an interest deduction or a lower interest rate pass through to the price of a new car. I find that the price of a new car responds negatively to changes in the after-tax real interest rate. The parameter estimates suggest that a one percentage point increase in the after-tax real interest rate will prompt, on average, a mark-down of $\$ 106$. This suggests that at least some of the benefits of a reduction in the real after-tax interest rates pass through to the motor vehicle suppliers. In related work, Goolsbee [1995] finds that the benefits of investment tax credits are passed through to the capital goods suppliers in the form of higher prices.

The public economics literature has focused on the incidence of taxation, or the effect of tax on price. The main thrust of this literature is that the difference between the nominal and real burdens of taxation depends on the market characteristics and the relevant price elasticities. Until recently, the theoretical literature of sales tax incidence focused on two extreme cases, monopoly and perfect competition. Prices are typically expected to shift by just the amount of the tax in the case of perfect competition and by less than the amount 
of the tax in the case of monopoly. A recent extension of the theoretical literature focuses on the implications of imperfect competition for the incidence of a sales tax and finds that price shifts might differ markedly from the theories based on standard assumptions. ${ }^{1}$ The primary results of this recent extension is that prices may overshift-i.e., shift up by more than the amount of the tax - in an imperfectly-competitive market. Besley [1989] considers the effects of taxation on the output per firm and the number of firms in an imperfectly competitive market. He finds that, with taxation, aggregate output always falls when the number of firms is endogenous. As a result, Besley's model suggests that overshifting is more likely in markets where entry is possible, as it prompts a larger change in the price.

There have been few empirical studies testing the hypotheses about incidence. Sullivan [1985] and Sumner [1981] use their estimated effects of excise taxes to determine the competitiveness of the cigarette industry. Poterba [1994] reviews early empirical work and tests the link between sales tax rates and city-specific clothing prices. His results suggest that retail prices rise by just the amount of the sales tax. Besley and Rosen [1994] examine more disaggregate data that allows them to analyze the incidence of a sales tax for 15 specific goods, including products such as the Big Mac and Crisco shortening, for a panel of 155 cities. They do find evidence of overshifting for some goods. A lack of specific information on market characteristics for the different products studied makes it more difficult to confirm that their range of results is exactly consistent with the theoretical literature.

Disparate results in the few empirical studies on sales tax incidence are not surprising given key differences in the data, such as commodities and time periods. Therefore, an evaluation of the new theories, as suggested in Poterba [1994], would require a more comprehensive picture with empirical evidence for several goods with a range of market characteristics. Typically, data preclude this kind of comprehensive study. In analyzing

\footnotetext{
${ }^{1}$ See Dellipalla and Keen [1992], Besley [1989], Stern [1987], Katz and Rosen [1985] and the references therein.
} 
the motor vehicle industry, I am able to study an imperfectly competitive industry with well-studied market characteristics. ${ }^{2}$ I find robust evidence of an overshifting of sales taxes on the price of a new car. This evidence of overshifting in an imperfectly competitive market offers some support for the recent models of tax incidence in these markets, such as Besley [1989].

Section 2 presents the empirical framework. Section 3 summarizes the data. The analysis utilizes a detailed micro survey, the Consumer Expenditure Survey (CEX). The advantage of the CEX is that it provides extensive information on consumers, their state of residence, and their expenditures. Crucially, the CEX provides extremely detailed information on motor vehicle purchases, including model type, list price, actual price, special financing, and additional options. Section 4 reports the main findings. Section 5 considers various tests and extensions and Section 6 concludes.

\section{Empirical Framework}

Differences in tax rates by state provides an exogenous variation to examine the relationship between taxes, interest rates, and the transaction price of a new car. A simple model of a motor vehicle purchase will serve to motivate the estimating equation. The model assumes that the observed price at which a motor vehicle sells is the result of bargaining between consumer and dealer.

Define $q_{i s t}^{m}$ to be the sales-tax-inclusive price for a car purchased by consumer $i$, define $p_{i s t}^{m}$ to be the sales-tax-exclusive price, and define $\tau_{s t}$ to be the sales-tax rate in the state of residence $s$ of consumer $i$ at time $t$. The prices are linked by the following identity:

\footnotetext{
${ }^{2}$ Several papers, including Bresnahan and Reiss [1985], Bresnahan [1981], and Berndt et al. [1990], provide detailed empirical evidence on the market structure and the price markups of the motor vehicle industry.
} 


$$
q_{i s t}^{m} \equiv p_{i s t}^{m}\left(1+\tau_{s t}\right)
$$

Equation (1) identifies the wedge driven by a state sales tax between the price paid by consumers and that received by suppliers.

The valuation of consumer $i$ for car model $m$ is denoted $V^{m}\left(\mathbf{X}_{i}\right)$, a function of a vector of the consumer's personal characteristics $\mathbf{X}_{i}$. The cost to dealer $d$ of supplying car model $m$ is denoted $C\left(\mathbf{X}_{d}, \mathbf{X}_{m}\right)$, a function of cost factors specific to dealer $d\left(\mathbf{X}_{d}\right)$ and cost factors specific to car model $m\left(\mathbf{X}_{m}\right)$. Because the majority of consumers finance a new car purchase, the ultimate cost of a new car depends on the interest rate as well as $q_{i s t}^{m}$. Let $R$ represent the real after-tax interest rate. Assuming that a multilateral bargaining game among the consumer and the dealers in the consumer's locality results in a certain car model $m$ being purchased from dealer $d$ at an agreed-upon price, a reduced-form equation of the following form will result:

$$
p_{i s t}^{m}=F\left(\mathbf{X}_{i}, \mathbf{X}_{d}, \mathbf{X}_{m}, \tau_{s t}, R\right)
$$

To take the simplest possible example, assume that consumer $i$ is served by a monopoly car dealer, and the consumer and a dealer engage in Nash bargaining, resulting in the car model being purchased that maximizes total surplus from the transaction at a price that divides the gains from trade equally between the parties. Equating the consumer's and dealer's gains,

$$
V^{m}\left(\mathbf{X}_{i}\right)-P V_{i s t}^{m}=p_{i s t}^{m}-C\left(\mathbf{X}_{d}, \mathbf{X}_{m}\right)
$$

where $P V_{i s t}^{m}$ is the present value of car payments (different from $q_{i s t}^{m}$ if the purchase is financed with a loan). In general, the dealer's markup over marginal cost will depend on the degree of local competition between dealers and the degree of competition between 
motor-vehicle manufacturers nationwide. ${ }^{3}$ Letting $\delta_{i}$ be the consumer's personal discount factor, if the price of the car is amortized over $k$ periods we have

$$
P V_{i s t}^{m}=\frac{\delta_{i}\left(1-\delta_{i}^{k}\right) R_{s t} q_{i s t}^{m}}{\left(1-\delta_{i}\right)\left[1-\left(1+R_{s t}\right)\right]^{-k}}
$$

More generally, $P V_{i s t}^{m}=f\left(R_{s t}\right) \cdot q_{i s t}^{m}$. Substituting equation (4) into equation (3), and substituting for $q_{i s t}^{m}$ from equation (1) and rearranging,

$$
p_{i s t}^{m}=\left[\frac{1}{1+\left(1+\tau_{s t}\right) f\left(R_{s t}\right)}\right]\left[V^{m}\left(\mathbf{X}_{i}\right)+C\left(\mathbf{X}_{d}, \mathbf{X}_{m}\right)\right]
$$

For estimation purposes, I use a linear specification as a first-order approximation to the relationship described in equation (2). Linearizing equation (5) by taking a first-order Taylor expansion around 0 yields ${ }^{4}$

$$
p_{i s t}^{m} \approx \alpha_{0}+\alpha_{1} \tau_{s t}+\alpha_{2} R_{s t}+\mathbf{X}_{i} \cdot \boldsymbol{\alpha}_{3}+\mathbf{X}_{d} \cdot \boldsymbol{\alpha}_{4}+\mathbf{X}_{m} \cdot \boldsymbol{\alpha}_{5}
$$

$\mathbf{X}_{i}$ includes various measures of specific household characteristics. The equation also controls for model-specific variables, $\mathbf{X}_{m}$, that affect the car model's wholesale cost. In addition, regional dummies, Region are added to control for the locational costs of the dealer, $\mathbf{X}_{d}$. Yearly dummies are included to capture macro effects that may affect the results when using a repeated cross-section. Note that the regional dummies and year indicators also have an effect on the transaction price through demand effects. With these additions, the resulting specification is

\footnotetext{
${ }^{3}$ See Bresnahan and Reiss [1985] and Bresnahan [1987] for further discussions of the market structure in the motor-vehicle industry. Smith [1981] describes the state regulations that limit the competition among auto dealers.

${ }^{4}$ It can be shown that $\alpha_{0}=K_{0}, \alpha_{1}=-f(0) K_{0} L_{0}, \alpha_{2}=-f^{\prime}(0) K_{0} L_{0}, \boldsymbol{\alpha}_{3}=L_{0} \nabla V^{m}(\overrightarrow{0}), \boldsymbol{\alpha}_{4}=$ $L_{0} \nabla_{1} C(\overrightarrow{0}, \overrightarrow{0})$ and $\boldsymbol{\alpha}_{5}=L_{0} \nabla_{2} C(\overrightarrow{0}, \overrightarrow{0})$, where $L_{0}=[1+f(0)]^{-1}$ and $K_{0}=L_{0}\left[V^{m}(\overrightarrow{0})+C(\overrightarrow{0}, \overrightarrow{0})\right]$. The notation $\nabla_{1} C$ refers to the gradient of $C$ with respect to $\mathbf{X}_{d}$ and $\nabla_{2} C$ the gradient with respect to $\mathbf{X}_{m}$.
} 


$$
p_{i s t}=\beta_{0}+\beta_{1} \tau_{s t}+\beta_{2} R+\beta_{3} X_{i}+\beta_{4} X_{d}+\beta_{5} X_{m}+\text { Region }_{i}+\text { Year }_{t}+\epsilon
$$

Equation (7) is comparable to that in Besley and Rosen [1994], though here it is tailored to consumer level data. As noted in Besley and Rosen, this reduced-form approach avoids some of the problematic assumptions of a more structural approach. Studies with structural models must make assumptions about the functional form of cost and demand. ${ }^{5}$ Note that this approach does not estimate an elasticity of demand. ${ }^{6}$

In analyzing the incidence of the sales tax, the estimate of $\beta_{1}$ from equation (7) can be used to determine the extent that taxes are shifted to prices, in the manner described in Besley and Rosen [1994]. Let $\gamma$ indicate the degree that taxes are overshifted into prices, the ultimate effect on $q_{s t}$ from an excise tax. An increase in tax revenue, $d x$, raised from an excise tax, $\tau_{s t}$ on a motor vehicle purchase, will raise the tax-inclusive price, $d q_{s t}$,

$$
\frac{d q_{s t}}{d x}=1+\frac{d p_{s t} / d \tau}{p_{s t}+\tau_{s t} \cdot\left(\partial p_{s t} / \partial \tau_{s t}\right)}=1+\gamma
$$

For small $\tau$, the overshifting parameter, $\gamma$ is

$$
\gamma \equiv \frac{\beta_{1}}{\bar{p}+\tau_{s t} \cdot \beta_{1}} \approx \frac{\beta_{1}}{\bar{p}}
$$

where $\bar{p}$ is the average price of a motor vehicle.

Note that under standard monopoly assumptions, theory would predict that $\beta_{1}$, and thus $\gamma$ would be negative, while under standard perfect competition assumptions, theory would predict that $\beta_{1}$, and thus $\gamma$ would be zero. In an imperfectly competitive market,

\footnotetext{
${ }^{5}$ Examples include Sullivan [1985] and Sumner [1981], both studied the cigarette industry using a more structural approach.

${ }^{6}$ See Berry [1994], Berry et al. [1992] and Goldberg [1994] for a comprehensive examination of the model of automobile demand.
} 
overshifting may occur and, in this case, both $\beta_{1}$ and $\gamma$ would be positive.

It is true that a variety of outcomes are possible in imperfectly competitive markets. According to the theoretical literature, the results depend on several factors, including the shape of the demand curve. As we know relatively little about the shape of demand curves, our conclusions about tax burdens must ultimately be drawn from empirical evidence. Nonetheless, the theoretical models, such as Besley [1985] do suggest that, in industries with entry, eventual overshifting is more likely.

At the dealership level, the motor vehicle industry can be characterized as an imperfectly competitive market with entry. Because the vast majority of cars are bought within seven miles of the consumer's home, the relevant market is a local one. ${ }^{7}$ Thus, a state presumably contains a number of local markets. Table 1 demonstrates there is substantial movement by new car dealers into and out of the markets within a state. Though the overall trend of car dealers during the eighties was to exit, both entry and exit can be observed.

The ultimate effect of taxes on prices emerges only after the market has time to adjust. Thus, the long run effects are, in fact, the results of interest. In addition, sales taxes change infrequently. The results of this study reflect the long-run effects of taxes on motor vehicle prices as the analysis uses primarily cross-sectional variation.

\section{The Data}

The primary data source for this paper is the Consumer Expenditure Survey (CEX). Originally, the Bureau of Labor Statistics' conducted the CEX survey in order to compute expenditure weights used in the construction of the consumer price index (CPI). As a result, the BLS has produced a data set that is unique in its level of detail regarding

\footnotetext{
${ }^{7}$ See Ward's Automotive Reports (July 1995), which presents survey results regarding motor vehicle purchases.
} 
consumption. The data set includes approximately 5,000 observations per year, collected from 85 different urban sampling areas corresponding mainly to Standard Metropolitan Statistical Areas as defined in $1970 .{ }^{8}$ Each observation pertains to a consumer unit, comprised of members of a household or other living group that share at least two of three major expense categories: housing, food, or other living expenses. ${ }^{9}$ Each consumer unit is interviewed for four consecutive quarters, resulting in a rotating panel. Motor-vehicle purchases, however, are typically infrequent, making the panel aspects of the data irrelevant; the dataset, effectively, is a repeated cross-section.

The revolving nature of the CEX generates twelve months of information for a household that can begin at any point within the calendar year. In order to link fiscal data with the CEX, I must pick the appropriate calendar year for each respondent. The relevant year is assigned to be the year that contains the most months covered by the respondent's answers. For example, a consumer unit that is surveyed from November, 1987 to October, 1988 will be considered an observation in 1988. I use observations within the calendar years 1983 to 1989. This time period is the most useful because the Tax Reform of 1986 completely phases out the interest deductibility in 1990, and the home equity became another popular form of deduction.

In a study that looks specifically at motor-vehicle consumption, Goldberg [1993] finds the CEX to be representative of the U.S. population both in terms of socioeconomic data and in terms of motor vehicle consumption patterns. Moreover, Cutler and Katz [1991] scrutinize these data and conclude that the spending information appears accurate but the income data may be under-reported. To illustrate the data, Table 2 presents summary

\footnotetext{
${ }^{8}$ They also survey several rural areas but they provide no geographical information about these respondents. As a consequence, they are not included in this study. This appears to be a minor omission for the purposes of our study, however, as Bresnahan and Reiss [1985] note that the vast majority of new cars are bought in urban areas.

${ }^{9}$ For a description of these categories, see the U.S. Bureau of Labor Statistics [1985], p. 132.
} 
statistics from the CEX for the general survey, for only those who bought new cars, and for only those who financed a new car purchase. The table demonstrates that within the CEX, six percent of the respondents bought a new car. Of the new car buyers, 77 percent financed their purchase. Those who purchased new cars tended to have a slightly higher level of income and nondurable consumption. On average, a consumer who financed a new car purchase was younger and had a lower level of financial assets compared to the whole population of new car buyers.

The CEX contains a substantial amount of information on the stock of motor vehicles owned and purchased by each household, in addition to information on household characteristics and general spending patterns. The data includes information on the make, model, model year, and purchase year of each vehicle. Using information on the vehicle characteristics, the car purchase was linked with model information from the Ward's Yearbooks (1983-1989). The remainder of the section provides further explanation of variable construction, with a concise list of variables provided in Appendix I.

\subsection{The Construction of Policy Variables}

This paper analyzes the extent to which car prices reflect the tax code by exploiting the variation in tax rates across states. I supplement the CEX data with the fiscal data necessary for the estimation by using information on the state of residence and the year of the purchase. Two key tax variables are necessary for this project: the income tax rates, which influence the magnitude of one's deductions of interest rate payments for a motor vehicle purchase, and the sales tax rate. Significant Features of Fiscal Federalism published annually by the Advisory Council on Intergovernmental Relations is the primary source of information for the tax code. The State Tax Handbook provided a check for the data and filled any gaps in the available years of information. Table 3 presents a sample of the 
tax rates for 1987; the sales tax rate in 1987 varies across states with a range of two to eight percent. Sales tax rates are rarely changed; one year of data presents an adequate picture as most of the tax variable's variation in this data is cross-sectional. Indeed, even in their panel estimation, Besley and Rosen [1994] find that their sales-tax rate variation is primarily cross-sectional.

The sales tax rate variable, $\tau_{s t}$, is the rate applicable to the purchase of a motor vehicle in state $s$ at time of purchase $t$, measured in percentage points. In most states, this rate equals the general sales tax rate but this is not uniformly true, as can be seen in Table 3. Given the lack of information about purchase location, I assume that the vehicle is purchased in the state where the respondent resides. An article in Ward's Reports (July 1995) reports that most consumers purchase their vehicle within seven miles of their residence, a fact that suggests my assumption is reasonable. In addition, it is noteworthy that the BLS makes the same assumption when they impute the sales tax.

The other key tax variable is a measure of the income tax savings that results from the tax deductibility of interest. This requires several pieces of information. First, we need to compute the relevant income tax rates at both federal and state level $\left(\tau^{F}\right.$ and $\left.\tau^{S}\right)$. Following the actual tax code as reprinted in the IRS publication, Statistics of Income (SOI), I construct the necessary variables for the NBER TAXSIM model to produce $\tau^{F}$ and $\tau^{S} \cdot{ }^{10}$

The NBER TAXSIM utilizes sixteen variables in determining a reasonable approximation of the respondent's tax rates. First, I denote the relevant year as the year that contains the most months covered by the respondent's answers. For filing status, married couples are assumed to file jointly while others are split accordingly into single and head of household categories. The number of dependents is set to be the maximum of two measures,

\footnotetext{
${ }^{10}$ See Feenberg and Coutts [1993] for more details on TAXSIM.
} 
the number of children under 18 or the number of family members, excluding household head and spouse, who are not considered earners. The number of age exemptions is set to be the number of taxpayers over 65 . Several income measures are used in TAXSIM. The wage and salary measures are entered separately for head of household and spouse in order to take account of second earner exemptions in early sample years. Dividend income is estimated to be the sum of interest earned, dividends, royalties, estates and trusts. A measure of other income includes earnings of the self-employed, fellowships, rental income, and alimony. TAXSIM uses the measures of pension income and social security income separately, as well as information on transfer income such as welfare, food stamps, and unemployment compensation. TAXSIM also accounts for the amount spent on rent, property taxes, and child care when calculating potential credits and deductions. Finally, TAXSIM utilizes an estimate of deductible expenses.

The CEX provides sufficient detail regarding expenditures to construct a measure of deductible expenses, excluding property and income taxes. I include health care expenditures and occupational expenditures that exceed the thresholds set by the federal tax code. In addition, sales tax was deductible prior to 1986. The tax forms in these years, found in IRS publications, provided optional sales-tax tables for a standardized sales-tax deduction based on family size, before-tax income and state of residence. The taxpayer had the option of deducting an amount greater than the amount determined by the sales tax table if receipts were kept. Using a measure of total consumption and state sales tax rates, I computed an estimate of all of the sales taxes that the household paid. Moreover, I accounted for sales-tax exemptions for clothing, food, health care and utilities. If my estimate of sales-tax paid exceeded the optional deduction by more than five percent, I used my estimate instead of the optional amount. The estimate of itemized deductions also includes charitable giving and eligible interest payments. 
I avoid potential endogeneity problems with this variable by excluding motor vehicle sales taxes and interest payments from the list of deductible expenses. In doing this, I have constructed the tax savings variable for the first dollar of interest payments. ${ }^{11}$

The relevant tax rate depends on the household's itemizer status. Comparing the estimate of itemized deductions that I calculate for TAXSIM to the standard deductions reported in the SOI, I determine a dummy variable for itemizer status $(I)$. With the 1986 Tax Reform, the interest deduction was phased out between 1987 and 1990. So each year, a declining fraction of the actual amount spent on interest could be deducted $(p h)$. The state income tax codes regarding the interest deduction follow the federal tax code. The relevant tax saving rate is

$$
\text { TaxScale }_{i}=p h *\left(1-I_{i} \cdot\left(\tau_{i}^{F}+\tau_{i}^{S}-\left(\tau_{i}^{F} \cdot \tau_{i}^{S}\right)\right)\right)
$$

I then compute a standard measure of the real after-tax interest rate $(R)$ for consumer $i$ using the new car finance rate for a 48 month loan at commercial banks (lrate) and the rate of inflation at time $t,\left(\dot{p}_{t}\right)$.

$$
R_{i s t}=\left(\left(1-\text { TaxScale }_{i s t}\right) \cdot \text { lrate }_{t}\right)-\dot{p}_{t} .
$$

\subsection{Information on Motor Vehicle Purchases}

The actual transaction price for each car purchase must be computed from several variables available in the CEX. The variable construction here is similar to that in Goldberg [1996]. For respondents who finance their motor vehicle purchase, I compute the actual transactions price as the sum of the down payment and the principal amount borrowed. As shown

\footnotetext{
${ }^{11}$ This approach is widely used in the charitable-giving literature. See Kingma [1989] and Feldstein [1975] for examples.
} 
earlier in Table 2, roughly three quarters of the respondents who purchase a new car finance their motor vehicle purchases. For those who do not finance their purchase, I compute the transaction price by adding the net purchase price after trade-ins and the trade-in allowance received. It is implicitly assumed here that the dealer does not offer concessions to the consumer in the form of an artificially high trade-in offer. Given the lack of specific data on the used vehicles that are traded in, it is impossible to determine whether bargaining between the consumer and the dealers affects the trade-in value of the old car.

An adjustment to the price must be made as the purchase price reported in the CEX includes sales tax. The vast majority of respondents, close to ninety percent, do not provide the sales tax information and BLS imputes this additional expense. They impute this tax amount using the general sales tax rate rather than motor vehicle sales tax rate, assuming that the vehicle was purchased in the state of residence. ${ }^{12}$

In order to control for differences between the car models, I include the suggested retail price, ListPrice, in the regression analysis. I use information from the Ward's Yearbook and match the list prices to the make and model recorded in the CEX. The information provided by the CEX sometimes lacks precision because of the existence of multiple versions of one model. In cases where there was difficulty making a precise match, I matched the purchased vehicle to the list price of the most basic and inexpensive model. To control for purchases of a better version of a model, I include all other available variables provided by the CEX on features of the actual car purchased. The features include automatic transmissions (Autotran), air-conditioning (Air Cond), number of cylinders $(C y l q)$, power brakes (Pwr Brake), and power steering (Pwr Steer). The list price used here includes destination fees, and hence, any indirect implications of the size of the price markup will

\footnotetext{
${ }^{12}$ I thank Bill Passero and his colleagues at the BLS for providing these facts.
} 
differ from the results of Goldberg [1996], where the data exclude destination fees.

\subsection{The Household Data}

The estimation of equation (7) also requires information about household characteristics. The remainder of the section will describe the household data which includes information about the household's stock of cars.

In this study, I use several measures of the financial status of the consumer unit, income (Income), financial assets (Fin Assets) and nondurable consumption (Consume). Nondurable consumption is the best available measure of permanent income. My methodology for constructing this variable follows Attanasio [1995]. Non-durable consumption is defined as total consumption minus expenditure on housing, health care, education and durable commodities. For those respondents that complete all four interviews, I define annual consumption as the sum of the twelve reported months of non-durable expenditures. These consumer units with complete interviews are then used to generate simple seasonal factors by regressing consumption on monthly dummies. For incomplete observations, I then use the seasonal factors to scale the available information into an annual figure. In a price equation, measures of wealth or income may have a positive effect on price, measuring the likelihood that a buyer will purchase extra, unobserved, features for the car which boosts its price. In contrast, measures of wealth or income may proxy for abilities that are correlated with bargaining ability, and thus may be negatively linked with price.

I also include other household characteristics such as age (Age) and education (Education) of the head of the consumer unit. As mentioned above, to the extent that these characteristics measure bargaining ability or the likelihood of being an informed consumer, we would expect a negative relationship with transaction price. On the other hand, an older, more educated person with a higher permanent income may purchase extras that are unmeasured 
in this data, resulting in a positive relationship.

Though not the primary focus of this paper, I control for the effect of possible dealer discrimination on transaction prices-the focus of Goldberg [1996]. The specification includes dummies for both female-headed households (Female), and minority-headed households (Minority). One limitation of these variables is that the CEX does not indicate which member of the consumer unit made the actual purchase. Implicitly, the use of these variables assumes that the head of the household makes the motor vehicle purchases.

I add regional dummies to control for potentially important regional variation: first, price may vary due to delivery fees, which vary by region; second, buying patterns may vary by part of the country suggesting the need to control for local demand. This dummy controls for some of the large variation in price across regions but does not eliminate all of the variation across states through the tax code. Yearly dummies, the unemployment rate, and U.S. income per capita control for fluctuations in the overall economy.

To account for a consumer's brand loyalty that may influence the transaction price, the estimation strategy uses dummies for those that did not own a car at beginning of their survey (First Car), and consumers who repeatedly buy the same brand (Loyal). This effect has been found in earlier work; Goldberg [1996] reports that the price elasticities of demand vary for different types of consumers. Intuitively, consumers making their first car purchases tend to be more responsive to price, and tend to be the target of more rebates from the dealerships. Consumers of more than one of a specific brand of car are less price responsive and more likely to have traded in a vehicle.

Several sets of dummies control for a multitude of effects, including the varying degree of popularity of the brands which affects the price markup. Specifically, I include brand dummies, and dummies for the different classes of vehicles such as Luxury, Truck, Van, Sport Car and Compact. For brevity, I also use a dummy that excludes all specialty cars, 
Not Specialty, specifically it excludes trucks, vans, sport utilities and luxuries. Following Goldberg [1996], I also control for the model year by creating dummies that reflect the time of year and whether the consumer bought last year's model, this year's model or next year's model.

\section{Results}

Because the data used in this study are household data rather than the more aggregated data used in similar tax studies, a different empirical approach is necessary. Specifically, the majority of the households in the CEX cannot be used in the price equation (7) because they did not purchase a new car. Estimating equation (7) in the standard way limits the sample to the fraction of the households making a new car purchase and could introduce a sample selection bias. To remedy the selection problem, I estimate Equation (7) using the data described in the previous section and a maximum likelihood estimation approach for sample selection (see Greene [1990] pp. 739-750) described in Appendix II.

The results from estimating Equation (7), using methodology described in Appendix II and the data described earlier, are reported in Table 4. Several variants of the estimation are presented as a check for robustness. A comparison of the results shows that the inclusion of year or brand dummies do not affect the coefficients of interest, though likelihood ratio tests reject the null hypothesis that the two set of dummies can be excluded-making the third column the preferred specification. As shown in the table, the coefficient on $\rho$ is significantly different from zero, suggesting that controlling for sample selection bias is necessary. ${ }^{13}$ The value of $\rho$ implies that the respondents with unobservable characteristics that make them more likely to purchase a car also have unobservable characteristics that make them more likely to get a lower price.

\footnotetext{
${ }^{13}$ See Appendix II for description of $\rho$ and the likelihood function.
} 
By utilizing the differences in tax codes across states and time, I derive the relationship between the after-tax real interest rate and price. The results suggest that the transaction price responds significantly to the real after-tax interest rate; the coefficient on $R$ is negative and significant in all specifications. The parameter estimates imply that a one percentage point increase in the real after-tax interest rate will prompt, on average, a price markdown of $\$ 106$. This implies that consumers pay a slightly higher price for a car when the real interest rate falls or the tax subsidy to interest payments rises. The following simple example puts the result in perspective. Suppose a consumer buys a car for $\$ 10,000$, roughly the average real price of a car in this sample, and finances the purchase with a ten percent down payment. The results suggest that this consumer would pay $\$ 106$ less for a new car if the real after-tax interest rate were one percentage point higher. For simplicity, I ignore discounting in this example. As described, the drop in price would more than offset the additional interest payments as a result of the interest rate increase, if the purchase was financed for one year. If the purchase were financed for four years, close to the average length of financing, then the price reduction would only offset about half of the increase in interest payments.

In addition, the results in Table 4, together with equation (9) provide evidence of an overshifting of taxes onto prices in the motor vehicle industry. Specifically, the coefficient on $\tau_{s t}$ is positive and significant at the one percent level in all four specifications. Though not presented, results that also use the interactions of the sales tax rate with dummies for all of the motor vehicle categories suggest that we cannot reject the null hypothesis that $\beta_{1}$ is equal across most types of motor vehicles. The category for compact cars, however, has a significantly smaller coefficient, shown in the second row of Table 4 . In fact, an F-test suggests that the overshifting parameter for compact cars is not significantly different from zero at the ten percent level. This finding is not inconsistent with the findings in Bresnahan 
and Reiss [1985] that both manufacturers and dealers have substantially less market power in the markets for the cheaper, compact cars compared to high-valued cars. Bresnahan [1981] explains that there are more substitutes within the compact category and, thus, the margins are smaller.

As shown in equation (9), the overshifting parameter, $\gamma$, is approximately $\beta_{1} / p$ if the tax rate is relatively small. Using the mean price of a vehicle in each category, Table 5 presents the overshifting parameter for several categories of motor vehicles. The table uses the appropriate coefficient from the fourth column of Table 4 and the mean price in its category to compute $\gamma$. Given the results, the differences across the motor vehicle categories (with the exception of compact cars) stem only from differences in price. Any $\gamma$ that is greater than zero implies that the tax is overshifted. Table 5 illustrates that taxes are estimated to significantly overshift for the all categories of motor vehicles, except for Compacts. For example, the overshifting parameter for a luxury car is 1.19 which implies that a change in the tax rate that generates $\$ 1$ of revenue per vehicle sale increases $q$, the tax-inclusive price, by $\$ 2.19$.

Turning back to Table 4, other results are noteworthy. Changes in list price do not translate one-for-one into a change in the transaction price. With regards to specific features of the car, the results are sensible; the presence of extra features, such as Air Cond, Pwr Steer, and Pwr Brake significantly increased the price of a car. The other characteristics, such as the number of cylinders and automatic transmission do not have significant coefficients; I could not reject the null hypothesis that these variables had zero effect in the equation so for the sake of brevity, the coefficients are not reported. Transactions prices are also significantly higher for specialty vehicles including trucks, vans, luxuries, and sport utilities. I, however, could not reject the null hypothesis that the price markup was the same for the four specialty categories of vehicles. For brevity, I report a single coefficient 
for vehicles that are not in a special category, Not Specialty.

Regarding household characteristics, education and the measures of wealth are the only variables that have a significant effect on the transaction price. The negative and significant coefficient on both Education and Income may reflect the consumer's negotiating abilities, suggesting that, perhaps, the more educated consumer is better able to extract rents from the dealer. Both the nondurable consumption and financial assets variables have a positive relationship with price. This may suggest that wealthier consumers are buying options for their car that are not observed in the data.

Like Goldberg [1996], I find that the average cost of a car does not significantly depend on a household-head being female or a minority. These characteristics, as well as age and variables describing the consumer's car stock were insignificant and not reported. The sets of dummies variables for region, year, brand, and timing of purchase are all important controls which are included in the regressions but not reported. Among these controls, there were a few noteworthy results. I find that the cost of a car is significantly less in the Midwest and significantly less for last year's model. The results for the unemployment rate and U.S. income per capita, controlling for overall economic conditions, were mixed and mostly insignificant.

Because an in-depth analysis of the decision to buy a car is beyond the scope of this paper, I relegate the selection equation to the end of the paper, in Table 9. Despite the simple approach of this equation, the results provide some sensible implications and warrants further study. First an increase in the after-tax real interest rate or the sales tax rate slightly reduces the probability of buying a car. The current measures of income have little bearing on the likelihood of a car purchase while nondurable consumption, a better measure of permanent income, does. More education, adults in the household, or earners in the household increase the likelihood of purchasing a car. The number of cars in the 
household before a new purchase also has a positive relationship with the transaction price. The coefficient for the dummy for the consumer units that have no car suggests that those without a car are far less likely to purchase a new car while consumers with several of one brand of car, Loyal, are more likely to make a purchase. The number of children under 16 in the consumer unit, has a negative effect on the likelihood that the family will buy a new car.

\section{$5 \quad$ Further Issues and Results}

In this section, I extend the results of the previous section in several ways. First, I examine two potentially important sources of omitted variable bias that may confound the resultslocal tax systems and heterogeneity across states in the form of average income. I then test the sensitivity of my results to the choice of estimation technique. Finally, I examine the determinants of the financing terms of a new car purchase to have a complete picture of the effect of government intervention on the overall cost of a new car.

\section{$5.1 \quad$ State Heterogeneity}

An omitted variable bias is one concern regarding the results of the previous section. Such a bias of the coefficients could creating misleading policy implications. Heterogeneity across states might cause such a bias. For example, wealthier regions of the country may have higher overall demand for vehicles and, as a result of local market conditions, pay more for a car. If the relatively wealthier states also tend to have higher sales tax rates, then the positive coefficient on $\tau_{s t}$ may only reflect the omitted variable bias. To check for evidence of this problem, I add a state per-capita income measure to the fourth column of Table 4 . This variable represents the real income per capita within the state of residence at the 
time of purchase. The coefficient on state income is insignificant and does not influence the parameters of interest. A likelihood-ratio test does not reject, at the five percent level, the null hypothesis that this variable may be excluded from the equation. Thus, there is no evidence that this form of bias is driving the key results.

\subsection{Local Taxes}

Due to a lack of information on the precise location of residence, it is impossible to assign the appropriate amount of local taxes applied to a new car purchase. As a result, both municipal and county sales taxes and property taxes are excluded from the regressions shown earlier. Note that BLS imputes the taxes for most purchases in the CEX facing the same difficulties and takes the same approach. The exclusion of these local taxes may be a possible source of omitted variable bias that could affect the results. If states with higher sales tax rates also tend to be states with more local taxes, then the positive coefficient on $\tau_{s t}$ may reflect the missing variable and not overshifting.

I explore this possibility with state level fiscal data. Because the data varies little over time, I use only one year, 1987, for my analysis. The available measures of local taxes include dummy variables for states that contain localities that impose a sales tax or property tax on motor vehicles. Fewer than half of the states impose at least one form of local taxes. To test, I regress the tax indicators on the state population, state income per capita, and the sales tax rates for motor vehicles. The first two columns of Table 6 present results from probit regressions using two tax indicators. The results provide no evidence that states with high sales taxes are more likely to impose local taxes.

As an additional test, I examine the median local sales tax rate as another measure of the local tax burden within a state. If the state has no local sales taxes, then the median is simply zero. A tobit regression, similar to the regressions of the first two columns of 
Table (6), provides no evidence that states with high sales tax rates have high local taxes. These results suggest that it is not unreasonable to assume that the omitted variables for local taxation are uncorrelated with the variables used in the analysis above and, thus, do not bias the results.

\subsection{Empirical Methodology}

I present alternative estimation techniques to illustrate that the results are not sensitive to the choice of methodology. First, I run equation (7) using OLS instead of a sample selection model. The results, presented in Table 7, are not different from the results of Table 4 in any substantive way. The lack of difference suggests that the sample selection approach does not change the results despite the fact that the estimate of $\rho$ in Table (4) is significantly different from zero, which rejects the null hypothesis that controlling for the bias is unnecessary. The OLS results do provide a useful comparison to results with generalized Huber-White standard errors that correct for intra-cluster correlation. ${ }^{14}$ This form of bias may be problematic in studies using the CEX because the survey is one with random interviewing within pre-determined sampling areas. It is possible that the variance of some variables is smaller within a sampling area than between sampling areas. As a consequence, the standard errors may be underestimated. To correct for this bias, I compute the more robust standard errors using the state of residence as a close proxy to sampling areas. The results, shown in Table (7) suggest that the standard errors do look slightly different, but not in a way that would change our interpretation of the significance of the variables of interest.

\footnotetext{
${ }^{14}$ Deaton and $\mathrm{Ng}$ [1993] address sample clustering and its bias of the standard error. Several references are provided therein.
} 


\subsection{Evidence on Financing}

Both dealers and manufacturers may alter the final cost of a new car not just with price but with financing terms. Because the price of a car is not the only factor affecting the cost to the consumer for a new car, I also examine the effects of fiscal and monetary policy on the financing terms of motor vehicle purchases. Anecdotal evidence often suggests that the motor vehicle industry does indeed offer special financing deals, as well as rebates, to entice consumers. Table 8 presents the results of estimations that are similar to those described in the previous section but with price replaced by a series of dependent variables that capture the financing situation of a car purchase: the self-reported real after-tax interest rate, the length of the financing period in years, the amount of the down payment, and the ratio of the down payment to the purchase price. The first stage results are shown at the end of the paper, in Table 9.

The results in Table 8 suggest that the sales tax rates have no significant effect on the financing rate or the down payment. The effect on the financing period appears significantly different from zero, but trivially so. The results in the first column also suggest that the self-reported interest rate charged moves in line with the 48-month bank rate, as the coefficient on the $R$ is essentially one, providing no evidence that financing terms are part of the negotiations. The other noteworthy results include the effect of $R$ on the size and relative size of the down payment, shown in the third and fourth columns. The real aftertax interest rate does have a positive effect on the relative size of the down payment. Nonetheless, there is no clear empirical evidence to significantly support the notion that most consumers simultaneously get price reductions and improved financing terms. 


\section{Conclusion}

This study has utilized the variation in the tax codes across states and data from the CEX to produce results that suggest that both the sales tax rate and the after-tax real interest rate influence the price of a new car. Thoroughly examining the actual decision to make a new car purchase is beyond the scope of this study, and it will be the subject of future research.

While interpreting the results, it is worth noting that motor vehicles purchases are unique; consumers must register new vehicles and, hence, cannot avoid taxes by crossing state borders. Nonetheless, the results are still useful. Motor vehicle purchases are still a nontrivial portion of one's total consumption bundle and an important industry in the economy.

The empirical results of this paper have provided evidence that sales taxes are overshifted onto the price of a new car, a result that is consistent with models of tax incidence in imperfectly competitive markets. The parameter estimates suggest that motor vehicle prices, except in the case of the compact car, increase by more than the amount of the sales tax. In the case of the compact car, a product with less market power than other motor vehicles, we cannot reject the null hypothesis that price increases are just equal to the amount of the sales tax.

The evidence of overshifting highlights the fact that studies of tax burdens, such as the CBO study of value-added taxes, may underestimate the tax burden to the consumer when using the standard assumption that price increases are just equal to the amount of a newly imposed sales tax. Underscoring the importance of understanding the potential burdens of

excise taxes, a recent study (Metcalf [1995]) suggests that the government will be forced to search for additional taxes, such as a consumption tax, in its effort to reduce the deficit.

In addition, the results imply that a one percentage point increase in the real after-tax 
interest rate will trigger a markdown of $\$ 106$ in the price of a new car. There is little evidence to suggest that special financing terms tend to accompany these price reductions. With regards to fiscal policy, the subsidies to car purchasers through the interest deduction from one's income tax appear to have given car dealers unintended rents, suggesting that the recent elimination of these subsidies extracted these rents. With regards to monetary policy, the results have similar implications; an increase in the interest rate translates into some reduction in price per vehicle transacted, which translates into a profit loss for either the dealer or the manufacturer in their efforts to promote sales. 


\section{Appendix I}

\section{Summary of Variables}

\section{Policy Variables:}

$R:$

$\tau_{s t}:$

Household Characteristics:

Adults:

Age:

Children:

Consume:

Earners:

Education:

Female:

Fin Assets:

Income:

Minority:

Vehicle Characteristics:

Financed:

First Car:

ListPrice:

Loyal:

Not Specialty:

Vehicles: after-tax real interest rate

sales tax rate for motor vehicle purchases in state $s$ at time $t$

number of members in the consumer unit over 16

age of the consumer-unit head

number of members of consumer unit under age 16

nondurable consumption of consumer unit (1982\$)

number of earners in consumer unit

number of years of education of consumer-unit head

dummy for consumer unit with female head

sum of savings, checking, U.S. bonds and stocks (1982\$)

income after taxes $(1982 \$)$

dummy for consumer unit with minority as head

dummy for car purchase that was financed

dummy for first car purchase

list price $(1982 \$)$

dummy for purchases where owner owns other of same brand dummy for new purchases that are not in the Luxury, Van, Truck or Sport Utility classes

number of vehicles owned excluding any current purchases 


\section{Appendix II}

\section{Sample Selection Model}

Let $F$ represent the cumulative probability function for the normal distribution for observation, $j$. The participation equation can be written as

$$
\operatorname{Buycar}_{j}=\omega \cdot X+\mu
$$

$P$ equals 1 if Buycar $_{j}>0$ and 0 otherwise. If $P$ equals 0 then the observation is unobserved in Equation (7). If $P$ equals 1 then the regression equation can be estimated

$$
p_{i s t}=\beta_{0}+\beta_{1} \tau_{s t}+\beta_{2} R+X_{m}+X_{d}+X_{i}+\text { Year }_{i}+\epsilon
$$

where $(\mu, \epsilon) \sim$ bivariate normal $[0,0,1, \sigma, \rho]$. If $\rho$ is nonzero then an OLS estimation of the regression equation would result in biased coefficients.

To correct for this bias, let $\hat{y}_{1}$ equal the fitted value from the participation equation and $\hat{p}_{2}$ equal the fitted values from the regression equation. The log-likelihood function used to estimate these equations jointly is

$$
l l=P \cdot\left(\ln \left(F\left(\frac{\hat{y}_{1}+\left(p_{i s t}-\hat{p}_{2}\right) \rho / \sigma}{\sqrt{1-\rho^{2}}}\right)\right)-\frac{1}{2}\left(\frac{p_{i s t}-\hat{p}_{2}}{\sigma}\right)^{2}\right)+(1-P) \cdot \ln \left(F\left(-\hat{y}_{1}\right)\right) .
$$




\section{References}

Advisory Committee on Intergovernmental Relations. 1984, 1987, 1990. Significant Features of Fiscal Federalism. Washington D.C.

Attanasio, Orazio P. 1995. "Consumer Durables and Inertial Behavior: Estimation and Aggregation of (S,s) Rules". NBER Working Paper \#5282.

Berndt, Ernst R., Ann F. Friedlaender, and Judy Shaw-Er Wang Chiang. 1990. "Interdependent Pricing and Markup Behavior: An Empirical Analysis of GM, Ford, and Chrysler". NBER Working Paper \#3396.

Bernanke, Ben S. 1984. "Permanent Income, Liquidity, and Expenditure on Automobiles: Evidence from Panel Data". The Quarterly Journal of Economics. 99: 587-614.

Bernanke, Ben S. 1985. "Adjustment Costs, Durables, and Aggregate Consumption". Journal of Monetary Economics. 15: 41-68.

Berry, Steve. 1994. "Estimating Discrete Choice Models of Product Differentiation". Rand Journal of Economics. Summer 1994: 242-263.

Berry, Steve, John Levinsohn and Ariel Pakes. 1992. "Automobile Prices in Market Equilibrium". NBER Working Paper \#4264.

Besley, Timothy. 1989. "Commodity Taxation and Imperfect Competition: A Note on the Effects of Entry". Journal of Public Economics. 40: 359-367.

Besley, Timothy and Harvey S. Rosen. 1994. "Sales Taxes and Prices: An Empirical Analysis". Princeton: Princeton University Discussion Paper \#172.

Bresnahan, Timothy. 1981. "Departures from Marginal-Cost Pricing in the American Automobile Industry". Journal of Econometrics. XVII: 201-227.

Bresnahan, Timothy and Peter Reiss. 1985. "Dealer and Manufacturer Margins". The Rand Journal of Economics. 2: 257-268.

Commerce Clearing House, Inc. State Tax Handbook 1984-1990.

Congressional Budget Office. 1992. Effects of Adopting a Value-Added Tax.

Cutler, David and Lawrence F. Katz. 1991. "Macroeconomic Performance and the Disadvantaged," Brookings Papers on Economic Activity. 1-74.

Deaton, Angus and Serena Ng. 1993. "Parametric and non-parametric approaches to price and tax reform". Mimeo. 
Delipalla, Sofia and Michael Keen. 1992. "The Comparison Between Ad Valorem and Specific Taxation Under Imperfect Competition". Journal of Public Economics. 49: 351-68.

Feenberg, Daniel Richard, and Elizabeth Coutts. 1993. "An Introduction to the TAXSIM Model". Journal of Policy Analysis and Management. 12 no.1: 189-194.

Feldstein, Martin. 1975. "The Income Tax and Charitable Contributions: Part I-Aggregate and Distributional Effects". National Tax Journal. 28: 81-97.

Goldberg, Pinelopi K. 1995. "Product Differentiation and Oligopoly in International Markets: The Case of the U.S. Automobile Industry". Econometrica. 63: 891-951.

Goldberg, Pinelopi K. 1996. "Dealer Price Discrimination in New Car Purchases: Evidence from the Consumer Expenditure Survey". Journal of Political Economy. 104 no. 3: 622-654.

Goolsbee, Austan. 1995. "Investment Tax Incentives and the Price of Capital Goods". MIT mimeo.

Greene, William H. 1990. Econometric Analysis. New York: MacMillan.

Katz, Michael and Harvey S.Rosen. 1985. "Tax Analysis in an Oligopoly Model". Public Finance Quarterly. 13 no. 1: 3-19.

Kingma, Bruce. 1989. "An Accurate Measure of the Crowd-out Effect, Income Effect, and Price Effect for Charitable Contributions". Journal of Political Economy. 97: $1197-1207$.

Kotlikoff, Laurence and Laurence Summers. 1987. eds. Alan Auerbach and Martin Feldstein "The Theory of Tax Incidence". Handbook of Public Economics. Amsterdam: North Holland.

Mankiw, N. Gregory. 1982. "Hall's Consumption Hypothesis and Durable Goods". Journal of Monetary Economics. 10: 417-425.

Mankiw, N. Gregory. 1985. "Consumer Durables and the Real Interest Rate". The Review of Economics and Statistics. LXVII, no 3: 353 -361.

Metcalf, Gilbert E. 1993. "The Lifetime Incidence of State and Local Taxes: Measuring Changes During the 1980s". NBER Working Paper \#4252.

Poterba, James M. 1994. "Retail Price Reactions to Changes in State and Local Sales Tax". Cambridge: MIT mimeo.

Smith, Richard L. 1982. "Franchise Regulation: An Economic Analysis of State Restrictions on Automobile Distribution". Journal of Law \& Economics. XXV: 125-157. 
Stern, Nicholas. 1987. "The Effects of Taxation, Price Control, and Government Contracts in Oligopoly and Monopolistic Competition". Journal of Public Economics. 32: 133158.

Sullivan, Daniel. 1981. "Testing Hypotheses About Firm Behavior in the Cigarette Industry". Journal of Political Economy. 93: 586-598.

Sumner, Daniel A. 1985. "Measurement of Monopoly Behavior: An Application to the Cigarette Industry". Journal of Political Economy. 89: 1010-1019.

U. S. Bureau of Labor Statistics. 1984-1993. Interview Survey Public Use Tape Documentation. Washington D.C.

U.S. Internal Revenue Service. 1987. Tax Rates and Tables for Prior Years. Document 6583.

U.S. Internal Revenue Service. 1983-1990. Statistics of Income: Individual Income Tax Return Reports.

Ward's Communications. 1995. "Survey: Buyers Loyal to Brand, Not Dealers". Ward's Automotive Reports. July 24: 3.

Ward's Communications. 1984-1995. Ward's Automotive Yearbooks. 
Table 1: New Car Dealerships by State

\begin{tabular}{|c|c|c|c|c|c|c|c|c|c|}
\hline State & 1980 & 1984 & 1988 & 1992 & State & 1980 & 1984 & 1988 & 1992 \\
\hline Alabama & 435 & 342 & 370 & 380 & Montana & 215 & 196 & 165 & 150 \\
\hline Alaska & 35 & 28 & 40 & 35 & Nebraska & 340 & 330 & 280 & 250 \\
\hline Arizona & 210 & 181 & 220 & 210 & Nevada & 75 & 75 & 77 & 80 \\
\hline Arkansas & 360 & 340 & 350 & 305 & New Hampshire & 180 & 162 & 182 & 181 \\
\hline California & 1,935 & 1,790 & 1,855 & 1,790 & New Jersey & 850 & 733 & 804 & 745 \\
\hline Colorado & $\begin{array}{l}1,300 \\
335\end{array}$ & 284 & $\begin{array}{l}1,000 \\
285\end{array}$ & 270 & New Mexico & 160 & 149 & 148 & 133 \\
\hline Connecticut & 420 & 356 & 385 & 370 & New York & 1,715 & 1,392 & 1,415 & 1,375 \\
\hline Delaware & 75 & 67 & 74 & 70 & North Carolina & 810 & 698 & 763 & 720 \\
\hline Dist. Columbia & 20 & 9 & 10 & 8 & North Dakota & 210 & 212 & 159 & 131 \\
\hline Florida & $7 \overline{7} 5$ & 755 & 925 & 920 & Ohio & $1, \overline{375}$ & 1,165 & 1,160 & 1,090 \\
\hline Georgia & 685 & 598 & 655 & 600 & Oklahoma & 475 & 457 & 420 & 370 \\
\hline Hawaii & 60 & 68 & 56 & 64 & Ore & 350 & 308 & 315 & 284 \\
\hline Idaho & 175 & 163 & 145 & 130 & ylvania & 1,785 & 1,575 & 1,585 & 1,455 \\
\hline Illinois & 1,480 & 1,280 & 1,250 & 1,205 & Rhode Island & 110 & 91 & $\begin{array}{r}1,000 \\
96\end{array}$ & $\begin{array}{r}1,70 \\
89\end{array}$ \\
\hline Indial & 835 & 632 & 700 & 630 & Carolina & 365 & 299 & 338 & 325 \\
\hline Iowa & 735 & 614 & 545 & 490 & Dakota & 180 & 175 & 162 & 142 \\
\hline Kansas & 505 & 434 & 390 & 345 & Ten & 565 & 43 & 455 & 436 \\
\hline Kentucky & 460 & 362 & 365 & 360 & Tex & 1,590 & 1,558 & 1,515 & 1,375 \\
\hline Loul & 420 & 378 & 385 & 345 & Uta & 175 & 153 & 156 & 150 \\
\hline Main & 240 & 192 & 205 & 185 & nont & 130 & 106 & 110 & 100 \\
\hline Mary & 400 & 358 & 383 & 355 & & 675 & 583 & 640 & 690 \\
\hline Massachusetts & 740 & 680 & 615 & 565 & Was & 465 & 389 & 390 & 365 \\
\hline Michigan & 1,075 & 938 & 875 & 875 & Virginia & 330 & 281 & 260 & 230 \\
\hline Minn & 670 & 597 & 575 & 532 & Wisc & 845 & 781 & 735 & 670 \\
\hline Mississippi & 370 & 330 & 315 & 275 & Wyoming & 100 & 99 & 82 & 75 \\
\hline \multirow[t]{2}{*}{ Missouri } & 730 & 666 & 615 & 575 & & & & & \\
\hline & & & & & Total & 28,250 & 24,725 & 25,000 & 23,400 \\
\hline
\end{tabular}

Source: MVMA Motor Vehicles Facts \& Figures '92, p. 67. 
Table 2: Summary Statistics

\begin{tabular}{|c|c|c|c|c|c|c|}
\hline \multirow[b]{2}{*}{ Variable } & \multicolumn{2}{|c|}{$\begin{array}{l}\text { Whole } \\
\text { Sample }\end{array}$} & \multicolumn{2}{|c|}{$\begin{array}{l}\text { Buy } \\
\text { A New Car }\end{array}$} & \multicolumn{2}{|c|}{$\begin{array}{c}\text { Finance and Buy } \\
\text { A New Car }\end{array}$} \\
\hline & Mean & Std. Dev. & Mean & Std. Dev. & Mean & Std. Dev \\
\hline Age & 46.0 & 16.6 & 46.7 & 15.5 & 44.0 & 14.0 \\
\hline Education & 12.7 & 2.9 & 13.6 & 2.8 & 13.5 & 2.7 \\
\hline Family size & 2.9 & 1.7 & 2.8 & 1.5 & 3.0 & 1.5 \\
\hline Adults & 2.22 & 1.11 & 2.25 & 1.02 & 2.30 & 1.07 \\
\hline Children & 0.71 & 1.11 & 0.60 & 0.95 & 0.66 & 0.97 \\
\hline Vehicles & 2.19 & 1.47 & 1.30 & 1.15 & 1.30 & 1.16 \\
\hline Fin Assets (1982\$) & 9,731 & 24,789 & 12,722 & 29,754 & 5,702 & 16,744 \\
\hline Income $(1982 \$)$ & 22,842 & 18,768 & 23,582 & 21.922 & 22,430 & 20,036 \\
\hline Consume $(1982 \$)$ & 14,083 & 8,366 & 16,680 & 9,301 & 16,430 & 8,324 \\
\hline$\%$ Buy a Car & 6 & - & - & - & - & - \\
\hline$\%$ Finance New Purchase & - & - & 77 & - & - & - \\
\hline Finance Period (years) & - & - & - & - & 3.83 & 0.89 \\
\hline Down Payment (1982\$) & - & - & - & - & 1,257 & 1,867 \\
\hline Down Payment/Price & - & - & - & - & 0.12 & 0.15 \\
\hline
\end{tabular}

Notes: Statistics are based on the author's calculations using the CEX. 
Table 3: State-Level Tax Rates for 1987

\begin{tabular}{|c|c|c|c|c|c|c|c|}
\hline State & $\begin{array}{l}\text { Sales } \\
\text { Tax }\end{array}$ & $\begin{array}{c}\text { Auto } \\
\text { Sales } \\
\text { Tax }\end{array}$ & $\begin{array}{c}\text { Income } \\
\text { Tax }\end{array}$ & State & $\begin{array}{l}\text { Sales } \\
\text { Tax }\end{array}$ & $\begin{array}{c}\text { Auto } \\
\text { Sales } \\
\text { Tax }\end{array}$ & $\begin{array}{c}\text { Income } \\
\text { Tax }\end{array}$ \\
\hline Alabama & 4 & 1.5 & $2-5$ & Montana & 0 & 1.5 & $2-11$ \\
\hline Alaska & 0 & 0 & 0 & Nebraska & 4 & 4 & $2-5.9$ \\
\hline Arizona & 5 & 5 & $2-8$ & Nevada & 5.8 & 2 & 0 \\
\hline Arkansas & 4 & 4 & $1-7$ & New Hampshire & 0 & 0 & 0 \\
\hline California & 4.8 & 4.8 & $1-9.3$ & New Jersey & 6 & 6 & $2-3.5$ \\
\hline Colorado & 3 & 3 & 5 & New Mexico & 4.8 & 3 & $1.8-8.5$ \\
\hline Connecticut & 7.5 & 7.5 & 0 & New York & 4 & 4 & $3-8$ \\
\hline Delaware & 0 & 0 & $0-8.8$ & North Carolina & 3 & 2 & $3-7$ \\
\hline Dist. Columbia & 6 & 6.5 & $6-9.5$ & North Dakota & 5.5 & 5 & $2.6-12$ \\
\hline Florida & 5 & 5 & 0 & Ohio & 5 & 5 & $1-7$ \\
\hline Georgia & 3 & 3 & $1-6$ & Oklahoma & 4 & 3.3 & $0.5-6$ \\
\hline Hawaii & 4 & 4 & $2.3-10$ & Oregon & 0 & 0 & $5-9$ \\
\hline Idaho & 5 & 5 & $2-8.2$ & Pennsylvania & 6 & 6 & 2.1 \\
\hline Illinois & 5 & 5 & 2.5 & Rhode Island & 6 & 6 & $a$ \\
\hline Indiana & 5 & 5 & 3.2 & South Carolina & 5 & 5 & $3-7$ \\
\hline Iowa & 4 & 4 & $0.4-10$ & South Dakota & 5 & 3 & 0 \\
\hline Kansas & 4 & 4 & $2-9$ & Tennessee & 5.5 & 5.5 & 0 \\
\hline Kentucky & 5 & 5 & $2-6$ & Texas & 6 & 4.1 & 0 \\
\hline Louisiana & 4 & 5 & $2-6$ & Utah & 5.1 & 6 & $2.6-7.4$ \\
\hline Maine & 5 & 5 & $1-10$ & Vermont & 4 & 4 & $b$ \\
\hline Maryland & 5 & 5 & $2-5$ & Virginia & 3.5 & 3 & $2-5.8$ \\
\hline Massachusetts & 5 & 5 & 5 & Washington & 6.5 & 6.5 & 0 \\
\hline Michigan & 4 & 4 & 4.6 & West Virginia & 5 & 5 & $3-6.5$ \\
\hline Minnesota & 6 & 6 & $4-9$ & Wisconsin & 5 & 5 & $4.9-6.9$ \\
\hline Mississippi & 6 & 3 & $3-5$ & Wyoming & 3 & 3 & 0 \\
\hline Missouri & 4.2 & 4.2 & $1.5-6$ & & & & \\
\hline
\end{tabular}

Notes: ${ }^{a} 23.45$ percent of taxpayer's federal tax liability. ${ }^{b} 25.8$ percent of taxpayer's federal tax liability. 
Table 4: Basic Specification for Transaction Price of a New Car

\begin{tabular}{|c|c|c|c|c|}
\hline Variable & (1) & $(2)$ & $(3)$ & (4) \\
\hline$\tau_{s t}$ & $\begin{array}{l}174.8^{* * *} \\
(62.4)\end{array}$ & $\begin{array}{l}179.3^{* * *} \\
(62.6)\end{array}$ & $\begin{array}{l}178.0^{* * *} \\
(62.6)\end{array}$ & $\begin{array}{l}160.8^{* * *} \\
(64.9)\end{array}$ \\
\hline$\tau_{s t} \cdot$ Compact & $\begin{array}{l}-91.1^{* *} \\
(39.4)\end{array}$ & $\begin{array}{l}-91.7^{* *} \\
(39.5)\end{array}$ & $\begin{array}{l}-78.3^{*} \\
(42.0)\end{array}$ & $\begin{array}{l}-78.8^{*} \\
(42.0)\end{array}$ \\
\hline$R$ & $\begin{array}{l}-118.6^{* *} \\
(50.3)\end{array}$ & $\begin{array}{l}-107.6^{* *} \\
(51.0)\end{array}$ & $\begin{array}{l}-105.6^{* *} \\
(51.1)\end{array}$ & $\begin{array}{l}-104.0^{* *} \\
(51.1)\end{array}$ \\
\hline List Price & $\begin{array}{l}0.618^{* * *} \\
(0.028)\end{array}$ & $\begin{array}{l}0.621^{* * *} \\
(0.028)\end{array}$ & $\begin{array}{l}0.626^{* * *} \\
(0.031)\end{array}$ & $\begin{array}{l}0.626^{* * *} \\
(0.031)\end{array}$ \\
\hline Consume & $\begin{array}{l}0.042^{* * *} \\
(0.010)\end{array}$ & $\begin{array}{l}0.040^{* * *} \\
(0.010)\end{array}$ & $\begin{array}{l}0.037^{* * *} \\
(0.010)\end{array}$ & $\begin{array}{l}0.036^{* * *} \\
(0.009)\end{array}$ \\
\hline Income & $\begin{array}{l}-0.006 \\
(0.005)\end{array}$ & $\begin{array}{l}-0.006 \\
(0.005)\end{array}$ & $\begin{array}{l}-0.006 \\
(0.005)\end{array}$ & $\begin{array}{l}-0.006 \\
(0.005)\end{array}$ \\
\hline Fin Assets & $\begin{array}{l}0.007^{* * *} \\
(0.003)\end{array}$ & $\begin{array}{l}0.007^{* *} \\
(0.003)\end{array}$ & $\begin{array}{c}0.007^{* *} \\
(0.003)\end{array}$ & $\begin{array}{l}0.007^{* * *} \\
(0.003)\end{array}$ \\
\hline Education & $\begin{array}{l}-57.0^{*} \\
(30.4)\end{array}$ & $\begin{array}{l}-55.1^{*} \\
(30.7)\end{array}$ & $\begin{array}{l}-66.8^{* *} \\
(30.8)\end{array}$ & $\begin{array}{l}-66.7^{* *} \\
(30.8)\end{array}$ \\
\hline Pwr Steer & $\begin{array}{c}586.3^{*} \\
(312.2)\end{array}$ & $\begin{array}{c}603.7^{*} \\
(312.0)\end{array}$ & $\begin{array}{l}638.5^{* *} \\
(314.5)\end{array}$ & $\begin{array}{l}635.6^{* *} \\
(314.5)\end{array}$ \\
\hline Pwr Brake & $\begin{array}{c}548.6^{*} \\
(318.3)\end{array}$ & $\begin{array}{c}514.5^{*} \\
(318.6)\end{array}$ & $\begin{array}{c}584.8^{*} \\
(319.6)\end{array}$ & $\begin{array}{c}593.9^{*} \\
(319.6)\end{array}$ \\
\hline Air Cond & $\begin{array}{l}977.7^{* * *} \\
(213.0)\end{array}$ & $\begin{array}{l}992.0^{* * *} \\
(212.8)\end{array}$ & $\begin{array}{l}1052.9^{* * *} \\
(213.6)\end{array}$ & $\begin{array}{l}1068.2^{* *} \\
(214.2)\end{array}$ \\
\hline Not Specialty & $\begin{array}{l}-947.7^{* * *} \\
(195.7)\end{array}$ & $\begin{array}{l}-971.5^{* * *} \\
(195.7)\end{array}$ & $\begin{array}{l}-966.8^{* * *} \\
(212.2)\end{array}$ & $\begin{array}{l}-966.9^{\text {***}} \\
(212.2)\end{array}$ \\
\hline State Income & - & - & - & $\begin{array}{c}0.634 \\
(0.643)\end{array}$ \\
\hline Constant & $\begin{array}{l}-9245 \\
(9022)\end{array}$ & $\begin{array}{c}-1812 \\
(10826)\end{array}$ & $\begin{array}{c}-2534 \\
(10837)\end{array}$ & $\begin{array}{c}-2942 \\
(10836)\end{array}$ \\
\hline$\rho$ & $\begin{array}{l}-0.146^{* * *} \\
(0.054)\end{array}$ & $\begin{array}{l}-0.168^{* *} \\
(0.062)\end{array}$ & $\begin{array}{l}-0.149^{* *} \\
(0.061)\end{array}$ & $\begin{array}{l}-0.144^{* *} \\
(0.060)\end{array}$ \\
\hline $\begin{array}{l}\text { Year Dummies } \\
\text { Brand Dummies } \\
\text { Log-Likelihood }\end{array}$ & $\begin{array}{c}\text { no } \\
\text { no } \\
-21069\end{array}$ & $\begin{array}{c}\text { yes } \\
\text { no } \\
-21066\end{array}$ & $\begin{array}{c}\text { yes } \\
\text { yes } \\
-20969\end{array}$ & $\begin{array}{c}\text { yes } \\
\text { yes } \\
-20969\end{array}$ \\
\hline
\end{tabular}

Notes: Estimates for equation (7) using the sample-selection procedure with the data described in Appendix I. There are 25,813 observations with 2,202 actual purchases. Several of the control variables are not reported here, see text for details. First stage results reported in Table $9 .{ }^{*}$ Significantly different from zero at the ten percent level; ${ }^{* *}$ five percent level; ${ }^{* * *}$ one percent level. 
Table 5: The Overshifting Parameters

\begin{tabular}{l|c|cc|c}
\hline & \multirow{2}{*}{$\begin{array}{c}\text { Number of } \\
\text { Auto Category }\end{array}$} & \multicolumn{2}{|c|}{ Price } & $\gamma$ \\
& Observations & Mean & Std. Dev. & \\
\hline Compact & 685 & 8,062 & 2,556 & 1.23 \\
Intermediate & 686 & 9,970 & 2,906 & $1.79^{* * *}$ \\
Large & 114 & 10,752 & 3,788 & $1.66^{* * *}$ \\
Luxury & 217 & 14,950 & 5,583 & $1.19^{* * *}$ \\
Sport Car & 64 & 12,590 & 3,257 & $1.41^{* * *}$ \\
Van & 68 & 12,326 & 3,651 & $1.44^{* * *}$ \\
Truck & 227 & 9,493 & 4,091 & $1.87^{* * *}$ \\
\hline
\end{tabular}

Notes: The overshifting parameter, $\gamma$, indicates the extent that excise taxes are shifted to prices: $\gamma=100 \cdot \beta_{1} / p$ [see equation (9)]. The positive values are evidence of overshifting, as shown in equation (8). Asterisks indicate the $\beta_{1}$ used to compute $\gamma$ significantly different from zero at the one percent level.

Table 6: Evidence on Presence and Magnitude of Local Taxes

\begin{tabular}{l|ccc}
\hline & $\begin{array}{c}\text { Property } \\
\text { Taxes }\end{array}$ & $\begin{array}{c}\text { Local } \\
\text { Sales Tax }\end{array}$ & $\begin{array}{c}\text { Mean Sales } \\
\text { Tax Rate }\end{array}$ \\
\hline \multirow{3}{*}{ State Population } & -0.005 & 0.010 & 0.010 \\
State Income & $-0.004)$ & $(0.006)$ & $(0.010)$ \\
$\tau_{\text {st }}$ & $(0.001)$ & -0.001 & 0.001 \\
Constant & 0.041 & -0.003 & -0.283 \\
& $(0.11)$ & $(0.111)$ & $(0.228)$ \\
& 1.28 & 0.552 & -0.685 \\
& $(1.03)$ & $(1.131)$ & $(2.381)$ \\
\hline
\end{tabular}

Notes: Estimates from probit in first two columns and from tobit in the third column. 
Table 7: Alternative Techniques for Estimating The Transaction Price of a New Car

\begin{tabular}{|c|c|c|c|c|}
\hline \multirow[b]{2}{*}{$\tau_{s t}$} & \multicolumn{2}{|c|}{ OLS } & \multicolumn{2}{|c|}{ Huber-White } \\
\hline & $\begin{array}{l}163.6^{* * *} \\
(62.8)\end{array}$ & $\begin{array}{l}163.5^{* * *} \\
(63.1)\end{array}$ & $\begin{array}{l}163.6^{* * *} \\
(54.9)\end{array}$ & $\begin{array}{l}163.5^{* *} \\
(53.2)\end{array}$ \\
\hline$\tau_{s t} \cdot$ Compact & $\begin{array}{l}-92.6^{* *} \\
(39.8)\end{array}$ & $\begin{array}{l}-76.1^{*} \\
(42.7)\end{array}$ & $\begin{array}{l}-92.6^{* *} \\
(40.2)\end{array}$ & $\begin{array}{l}-76.1^{*} \\
(45.8)\end{array}$ \\
\hline$R$ & $\begin{array}{l}-132.1^{* * *} \\
(50.4)\end{array}$ & $\begin{array}{l}-112.9^{* *} \\
(51.6)\end{array}$ & $\begin{array}{l}-132.1^{* * *} \\
(36.8)\end{array}$ & $\begin{array}{l}-112.9^{* *} \\
(42.1)\end{array}$ \\
\hline List Price & $\begin{array}{l}0.619^{* * *} \\
(0.029)\end{array}$ & $\begin{array}{l}0.626^{* * *} \\
(0.032)\end{array}$ & $\begin{array}{l}0.619^{* * *} \\
(0.054)\end{array}$ & $\begin{array}{l}0.626^{* * *} \\
(0.056)\end{array}$ \\
\hline Consume & $\begin{array}{l}0.042^{* * *} \\
(0.010)\end{array}$ & $\begin{array}{l}0.037^{* * *} \\
(0.010)\end{array}$ & $\begin{array}{l}0.042^{* * *} \\
(0.009)\end{array}$ & $\begin{array}{l}0.037^{* * *} \\
(0.009)\end{array}$ \\
\hline Income & $\begin{array}{l}-0.007 \\
(0.005)\end{array}$ & $\begin{array}{l}-0.007 \\
(0.005)\end{array}$ & $\begin{array}{l}-0.007^{*} \\
(0.004)\end{array}$ & $\begin{array}{l}-0.007^{*} \\
(0.004)\end{array}$ \\
\hline Fin Assets & $\begin{array}{l}0.008^{* * *} \\
(0.003)\end{array}$ & $\begin{array}{l}0.007^{* * *} \\
(0.003)\end{array}$ & $\begin{array}{l}0.008^{* * *} \\
(0.003)\end{array}$ & $\begin{array}{c}0.007^{* *} \\
(0.003)\end{array}$ \\
\hline Education & $\begin{array}{l}-40.8 \\
(30.1)\end{array}$ & $\begin{array}{l}-51.5^{*} \\
(30.5)\end{array}$ & $\begin{array}{l}-40.8^{*} \\
(34.1)\end{array}$ & $\begin{array}{l}-51.5^{*} \\
(34.5)\end{array}$ \\
\hline Pwr Steer & $\begin{array}{c}584.5^{*} \\
(315.6)\end{array}$ & $\begin{array}{c}649.5^{* *} \\
(319.4)\end{array}$ & $\begin{array}{l}584.5^{* * *} \\
(215.3)\end{array}$ & $\begin{array}{l}649.5^{* * *} \\
(220.4)\end{array}$ \\
\hline Pwr Brake & $\begin{array}{c}541.3^{*} \\
(321.8)\end{array}$ & $\begin{array}{c}578.6^{*} \\
(324.5)\end{array}$ & $\begin{array}{l}541.3^{* * *} \\
(181.9)\end{array}$ & $\begin{array}{c}578.6^{* *} \\
(190.4)\end{array}$ \\
\hline Air Cond & $\begin{array}{l}1023.8^{* * *} \\
(214.7)\end{array}$ & $\begin{array}{l}1081.2^{* * *} \\
(216.6)\end{array}$ & $\begin{array}{l}1023.8^{* * *} \\
(156.8)\end{array}$ & $\begin{array}{l}1081.2^{* * *} \\
(178.9)\end{array}$ \\
\hline Not Specialty & $\begin{array}{l}-926.1^{* * *} \\
(197.7)\end{array}$ & $\begin{array}{l}-951.4^{* * *} \\
(215.4)\end{array}$ & $\begin{array}{l}-926.1^{* * *} \\
(245.4)\end{array}$ & $\begin{array}{l}-951.4^{* * *} \\
(266.5)\end{array}$ \\
\hline Constant & $\begin{array}{l}-16910^{* *} \\
(8640)\end{array}$ & $\begin{array}{c}-14265 \\
(9764)\end{array}$ & $\begin{array}{c}-16910^{*} \\
(9972)\end{array}$ & $\begin{array}{c}-14265 \\
(11772)\end{array}$ \\
\hline $\begin{array}{l}\text { Year \& Brand } \\
\text { Dummies }\end{array}$ & no & yes & no & yes \\
\hline
\end{tabular}

Notes: First two columns are parameter estimates for equation (7) with OLS standard errors. Last two columns are parameter estimates with Huber-White standard errors, correcting for intra-cluster correlation. The data are described in Appendix I. There are 2,202 observations. Several variables described in the text are included in the estimation as controls, but are not reported. 
Table 8: Other Factors in Car Purchase

\begin{tabular}{|c|c|c|c|c|}
\hline & $\begin{array}{l}\text { Finance } \\
\text { Rate }\end{array}$ & $\begin{array}{l}\text { Finance } \\
\text { Period }\end{array}$ & DownPay & DownPay/Price \\
\hline$\tau_{s t}$ & $\begin{array}{c}0.083 \\
(0.071)\end{array}$ & $\begin{array}{c}0.029^{*} \\
(0.016)\end{array}$ & $\begin{array}{c}24.0 \\
(34.0)\end{array}$ & $\begin{array}{c}0.292 \\
(0.339)\end{array}$ \\
\hline$R$ & $\begin{array}{l}1.02^{* * *} \\
(0.062)\end{array}$ & $\begin{array}{l}-0.007 \\
(0.014)\end{array}$ & $\begin{array}{c}36.1 \\
(29.6)\end{array}$ & $\begin{array}{l}0.008^{* * *} \\
(0.003)\end{array}$ \\
\hline List Price $(\times 1000)$ & $\begin{array}{c}0.015 \\
(0.021)\end{array}$ & $\begin{array}{l}-0.006 \\
(0.004)\end{array}$ & $\begin{array}{c}10.11 \\
(10.60)\end{array}$ & $\begin{array}{l}0.005^{* * *} \\
(0.002)\end{array}$ \\
\hline Consume $(\times 1000)$ & $\begin{array}{l}0.033^{* * *} \\
(0.011)\end{array}$ & $\begin{array}{l}0.006^{* *} \\
(0.003)\end{array}$ & $\begin{array}{c}4.71 \\
(5.88)\end{array}$ & $\begin{array}{c}-0.0006 \\
(0.0006)\end{array}$ \\
\hline Fin Assets $(\times 1000)$ & $\begin{array}{l}-0.012^{* *} \\
(0.006)\end{array}$ & $\begin{array}{l}-0.003^{* *} \\
(0.001)\end{array}$ & $\begin{array}{l}5.87^{* *} \\
(2.63)\end{array}$ & $\begin{array}{c}0.0002 \\
(0.0003)\end{array}$ \\
\hline Income $(\times 1000)$ & $\begin{array}{c}-0.002 \\
(0.006)\end{array}$ & $\begin{array}{c}-0.001 \\
(0.001)\end{array}$ & $\begin{array}{l}-11.8^{* * *} \\
(2.97)\end{array}$ & $\begin{array}{l}-0.0005^{*} \\
(0.0003)\end{array}$ \\
\hline Education & $\begin{array}{l}-0.084^{* *} \\
(0.037)\end{array}$ & $\begin{array}{l}-0.043^{* * *} \\
(0.008)\end{array}$ & $\begin{array}{l}50.2^{* * *} \\
(18.0)\end{array}$ & $\begin{array}{l}0.0038^{* *} \\
(0.0018)\end{array}$ \\
\hline Age & $\begin{array}{l}-0.012^{*} \\
(0.007)\end{array}$ & $\begin{array}{l}-0.011^{* * *} \\
(0.002)\end{array}$ & $\begin{array}{l}14.4^{* * *} \\
(3.44)\end{array}$ & $\begin{array}{l}0.0013^{* * *} \\
(0.0003)\end{array}$ \\
\hline Loyal & $\begin{array}{l}-0.154 \\
(0.265)\end{array}$ & $\begin{array}{l}-0.186^{* * *} \\
(0.060)\end{array}$ & $\begin{array}{l}404^{* * *} \\
(128)\end{array}$ & $\begin{array}{c}0.018 \\
(0.012)\end{array}$ \\
\hline First Car & $\begin{array}{c}-0.164 \\
(0.207)\end{array}$ & $\begin{array}{l}-0.097^{* * *} \\
(0.046)\end{array}$ & $\begin{array}{c}-74.0 \\
(100.2)\end{array}$ & $\begin{array}{l}-0.013 \\
(0.010)\end{array}$ \\
\hline Not Specialty & $\begin{array}{c}0.226 \\
(0.213)\end{array}$ & $\begin{array}{c}-0.008 \\
(0.047)\end{array}$ & $\begin{array}{c}-247.2 \\
(104.0)\end{array}$ & $\begin{array}{c}-0.002 \\
(0.011)\end{array}$ \\
\hline Constant & $\begin{array}{c}7.03 \\
(7.52)\end{array}$ & $\begin{array}{l}4.88^{* * *} \\
(1.70)\end{array}$ & $\begin{array}{l}-800 \\
(3735)\end{array}$ & $\begin{array}{c}0.310 \\
(0.599)\end{array}$ \\
\hline
\end{tabular}

Notes: Estimates from the regression equation of the sample-selection procedure described in Appendix II for equation (7). The data are described in Appendix I. First stage results from column (1) are reported in Table 9. 
Table 9: First Stage of Sample Selection Model

\begin{tabular}{|c|c|c|}
\hline Variable & Buy & Finance \\
\hline$\tau_{s t}$ & $\begin{array}{l}-0.039^{* * *} \\
(0.012)\end{array}$ & $\begin{array}{l}-0.047^{* * *} \\
(0.011)\end{array}$ \\
\hline$R$ & $\begin{array}{l}-0.024^{* * *} \\
(0.010)\end{array}$ & $\begin{array}{l}-0.068^{* * *} \\
(0.010)\end{array}$ \\
\hline Consume $(\times 1000)$ & $\begin{array}{l}0.0010^{* * *} \\
(0.0001)\end{array}$ & $\begin{array}{l}0.012^{* * *} \\
(0.002)\end{array}$ \\
\hline Income $(\times 1000)$ & $\begin{array}{c}0.0001 \\
(0.0001)\end{array}$ & $\begin{array}{c}0.0007 \\
(0.0009)\end{array}$ \\
\hline Fin Assets $(\times 1000)$ & $\begin{array}{l}-0.0001^{*} \\
(0.0001)\end{array}$ & $\begin{array}{l}-0.009^{* * *} \\
(0.0008)\end{array}$ \\
\hline Adults & $\begin{array}{l}0.071^{* *} \\
(0.024)\end{array}$ & $\begin{array}{l}0.054^{* *} \\
(0.022)\end{array}$ \\
\hline Children & $\begin{array}{l}-0.070^{* * *} \\
(0.016)\end{array}$ & $\begin{array}{l}-0.049^{* * *} \\
(0.014)\end{array}$ \\
\hline Earners & $\begin{array}{c}0.032^{*} \\
(0.023)\end{array}$ & $\begin{array}{l}0.104^{* * *} \\
(0.022)\end{array}$ \\
\hline Age & $\begin{array}{l}0.006^{* * *} \\
(0.001)\end{array}$ & $\begin{array}{l}-0.0007 \\
(0.0011)\end{array}$ \\
\hline Minority & $\begin{array}{l}-0.154^{* * *} \\
(0.047)\end{array}$ & $\begin{array}{l}-0.075^{*} \\
(0.042)\end{array}$ \\
\hline Female & $\begin{array}{c}0.034 \\
(0.034)\end{array}$ & $\begin{array}{l}-0.026 \\
(0.032)\end{array}$ \\
\hline Education & $\begin{array}{l}0.035^{* * *} \\
(0.006)\end{array}$ & $\begin{array}{l}0.021^{* * *} \\
(0.005)\end{array}$ \\
\hline Vehicles & $\begin{array}{l}-0.592^{* * *} \\
(0.019)\end{array}$ & $\begin{array}{l}-0.555^{* * *} \\
(0.017)\end{array}$ \\
\hline First Car & $\begin{array}{l}-0.396^{* * *} \\
(0.040)\end{array}$ & $\begin{array}{l}-0.363^{* * *} \\
(0.037)\end{array}$ \\
\hline U.S. Income & $\begin{array}{l}1.29^{* * *} \\
(0.064)\end{array}$ & $\begin{array}{l}0.801^{* * *} \\
(0.361)\end{array}$ \\
\hline
\end{tabular}

Notes: Estimates from the participation equation of the sampleselection procedure described in Appendix II for equation (7). Results correspond to the regression equation results shown in column (3) of Table 4 and column (1) of Table 8. The data are described in Appendix I. 